\title{
Pengaruh Perputaran Piutang dan Perputaran Persediaan Terhadap Profitabilitas Pada PT. Mustika Ratu Tbk.
}

\author{
Eni Puji Astuti ${ }^{1}{ }^{1}$ dan Sarah Aprianti ${ }^{2)}$ \\ ${ }^{1)}$ Dosen Universitas Pamulang, email : dosen00807@unpam.co.id
}

\section{ARTICLES \\ INFORMATION}

\section{ABSTRACT}

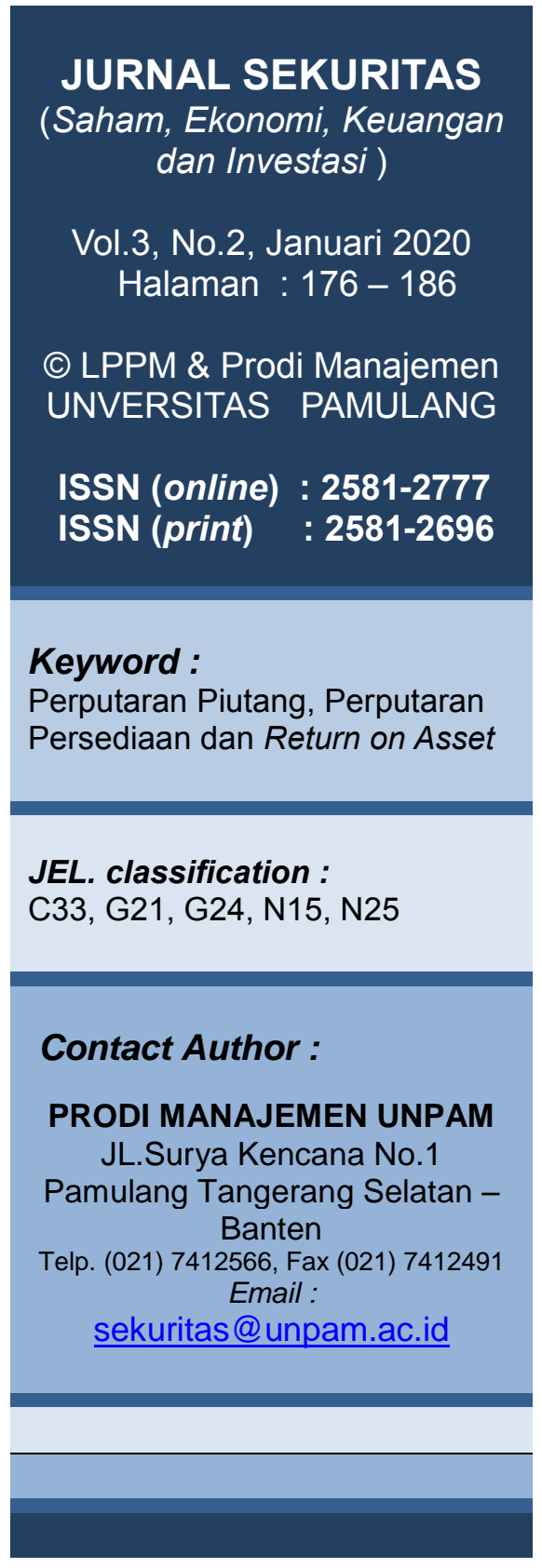

"Penelitian ini bertujuan untuk menguji pengaruh perputaran piutang dan perputaran persediaan terhadap profitabilitas" pada PT. Mustika Ratu, Tbk periode 2007 sampai dengan 2016.Variabel independen dalam penelitian ini yaitu perputaran piutang dan perputaran persediaan, sedangkan untuk variabel dependennya adalah profitabilitas. Penelitian ini menggunakan metode kuantitatif dengan teknik analisis regresi linier berganda, uji $\mathrm{F}$ dan uji t dengan alat bantu aplikasi SPSS (statistical product and service solutions). Hasil penelitian ini menunjukkan tidak terdapat pengaruh antara perputaran piutang terhadap profitabilitas, sedangkan terdapat pengaruh perputaran persediaan terhadap profitabilitas.

The purpose of this study to examine the effect of accounts receivable turnover and inventory turnover on profitability "at PT. Mustika Ratu, Tbk from 2007 to 2016. The independent variable in this study is the accounts receivable turnover and inventory turnover, while the dependent variable is profitability. This research uses quantitative methods with multiple linear regression analysis techniques, $F$ test and $t$ test with SPSS (statistical product and service solutions) application aids. The results of this study indicate there is no influence between accounts receivable turnover on profitability, while there is an influence of inventory turnover on profitability. 


\section{A. PENDAHULUAN}

Perkembangan teknologi terus meningkat di era sekarang ini, juga dengan banyaknya perusahaan sejenis yang nampak membuat persaingan menjadi semakin pesat. Ini membuat masalah manajemen lebih kompleks. Apalagi dengan kondisi ekonomi Indonesia yang tidak stabil, yang membuat banyak perusahaan kesulitan mempertahankan kelangsungan hidupnya. Ini sangat mempengaruhi kebijakan yang diadopsi oleh perusahaan. Tidak jarang bagi perusahaan untuk mengubah kebijakan yang saat ini sedang dilaksanakan

Perusahaan dituntut untuk selalu berinisiatif, kreatif, dan inovatif yang bertujuan untuk meningkatkan efisiensi dan produktivitas dalam upaya memenangkan pasar dan untuk selalu menyesuaikan diri dengan segala macam perubahan yang akan terjadi di masa depan, baik kondisi ekonomi, peraturan pemerintah, kondisi konsumen, serta kondisi pesaing. "Oleh karena itu perusahaan harus menumbuhkan, menjalankan dan membangun manajemennya secara konseptual dan sistematis melalui"pemanfaatan sumber daya perusahaan.

Seperti halnya dengan industri kosmetik di Indonesia, yang saat ini mengalami perkembangan yang sangat pesat sehingga situasi ini menciptakan persaingan bisnis yang kompetitif dan sengit. Populasi sekitar 250 juta orang menjadikan Indonesia pasar yang menjanjikan bagi perusahaan kosmetik. Meskipun sebagian besar industri kosmetik membidik target audiens utama wanita, baru-baru ini mereka mulai berinovasi dengan membuat produk untuk pria. Perkembangan industri kosmetik Indonesia cukup solid. Ini dapat dilihat dari peningkatan penjualan kosmetik pada 2012 sebesar 14\% menjadi Rp 9,76 triliun dari $\mathrm{Rp}$ 8,5 triliun, menurut data Kementerian Perindustrian. Asosiasi Perusahaan Kosmetik Indonesia (PERKOSMI) memperkirakan bahwa pada 2013 penjualan kosmetik naik menjadi Rp 11,2 triliun atau tumbuh 15\% dibandingkan dengan proyeksi 2012 sebesar Rp 9,76 triliun. Namun, saat ini,di pasar domestik produk kosmetik import menjadi tantangan untuk industri kosmetik dalam negeri. Menurut data Perkosmi, tahun lalu penjualan kosmetik impor mencapai Rp 2,44 triliun, naik 30\% dibandingkan 2011 yang sebesar $R p$ 1,87 triliun.

Seiring dengan perkembangan jaman, kosmetik tampaknya menjadi kebutuhan utama bagi sebagian wanita dan pria, hal ini menjadi peluang bagi perusahaan kosmetik di Indonesia. Salah satu perusahaan yang bergerak di industri kosmetik adalah PT. Mustika Ratu, Tbk, yang telah go public dan telah terdaftar di Bursa Efek Indonesia (BEI). Tujuan utama perusahaan secara umum adalah untuk mendapatkan keuntungan yang maksimal. Untuk memperoleh laba maksimum, salah satu kebijakan perusahaan yaitu dengan menambah jumlah produksi. Faktor terpenting yang digunakan oleh perusahaan untuk membiayai operasi perusahaan salah satunya adalah modal kerja. Unsur-unsur dalam aset lancar dalam membiayai operasi harian perusahaan harus selalu dalam keadaan berputar sehingga diperlukan manajemen yang baik. Dimana Komponen tersebut termasuk piutang dan persediaan. Dua komponen tersebut dapat dikelola dengan cara yang berbeda untuk memaksimalkan atau meningkatkan pertumbuhan perusahaan.

"Piutang merupakan komponen penting dari aset lancar dalam kegiatan ekonomi perusahaan karena merupakan aset lancar terbesar perusahaan setelah kas. Piutang ada dikarenakan terdapat transaksi penjualan barang atau jasa secara kredit, juga karena memberikan pinjaman. Piutang juga merupakan elemen modal yang selalu dalam keadaan berputar. "Perputaran piutang adalah rasio yang digunakan untuk mengukur berapa lama piutang dikumpulkan selama satu periode atau berapa kali dana diinvestasikan dalam rekening bergulir dalam suatu periode." Semakin cepat piutang berputar, itu berarti perusahaan lebih cepat dan lebih efisien dalam mengubah asetnya dan itu juga berarti peluang bagi perusahaan untuk mendapatkan keuntungan yang lebih besar. "Tingkat perputaran piutang yang tinggi berarti pengembalian dana yang tertanam dalam piutang cepat kembali."

Jurnal SEKURITAS (Saham, Ekonomi, Keuangan dan Investasi ), Vol.3, No.2 , Januari 2020........177 
Selain piutang, komponen lainnya adalah persediaan yang merupakan komponen utama modal kerja, karena persediaan bertindak sebagai sumber pendapatan bagi perusahaan yang dapat digunakan untuk membiayai kewajiban keuangan perusahaan, termasuk membiayai kegiatan operasional perusahaan atau kegiatan utama lainnya. Setiap manajemen perusahaan perlu melakukan kontrol yang optimal terhadap persediaan melalui perputaran persediaan untuk mengukur berapa kali dana diinvestasikan dalam bentuk persediaan yang berputar dalam satu periode. Inventory turnover (perputaran persediaan) adalah rasio yang digunakan untuk mengukur berapa kali dana yang diinvestasikan dalam inventaris ini berputar dalam suatu periode. Jika suatu perusahaan dapat mengelola persediaan dengan baik, maka perusahaan dapat segera mengubah persediaan yang disimpan melalui penjualan yang akan menghasilkan laba

Pada hakekatnya perputaran piutang dan perputaran persediaan memiliki hubungan yang sangat dekat dengan tingkat keuntungan atau profitabilitas perusahaan. Profitabilitas adalah perusahaan yang mendapat untung dari penjualan, total yang dibutuhkan sebagai modal sendiri. Salah satu cara untuk mencapai tujuan perusahaan adalah dengan meningkatkan profitabilitas perusahaan. Profitabilitas yang menunjukkan keunggulan perusahaan dalam persaingan bisnis. Profitabilitas akan memberikan gambaran tentang efektivitas manajemen perusahaan. Semakin tinggi tingkat profitabilitas, semakin baik perusahaan. Berdasarkan uraian di atas maka dapat disimpulkan bahwa modal kerjadapat mempengaruhi tingkat profitabilitas perusahaan. Profitabilitas dalam penelitian diproyeksikan pada Return On Asset (ROA) karena aktiva yang dimiliki PT. Mustika Ratu, Tbk selama 10 periode dari tahun 2007 sampai dengan 2016 mengalami naik turun namun cenderung naik sedangkan dibandingkan dengan laba bersih perusahaan selama 10 periode mengalami naik turun namun cenderung menurun yang dapat dilihat pada tabel 1

Tabel 1

Perputaran piutang, perputaran persediaan dan profitabilitas (ROA) PT. Mustika Ratu, Tbk periode 2007-2016.

\begin{tabular}{|c|c|c|c|}
\hline Tahun & $\begin{array}{c}\text { Perputaran } \\
\text { Piutang }\end{array}$ & $\begin{array}{c}\text { Perputaran } \\
\text { Persediaan }\end{array}$ & $\begin{array}{c}\text { Profitabilitas } \\
\text { (ROA) }\end{array}$ \\
\hline 2007 & 2,920 kali & 2,458 kali & $3,5 \%$ \\
\hline 2008 & 3,029 kali & 2,854 kali & $6,2 \%$ \\
\hline 2009 & 2,773 kali & 3,378 kali & $5,7 \%$ \\
\hline 2010 & 2,601 kali & 3,610 kali & $6,3 \%$ \\
\hline 2011 & 2,520 kali & 3,227 kali & $6,6 \%$ \\
\hline 2012 & 2,399 kali & 3,186 kali & $6,8 \%$ \\
\hline 2013 & 1,943 kali & 2,398 kali & $-1,5 \%$ \\
\hline 2014 & 2,244 kali & 2,431 kali & $1,4 \%$ \\
\hline 2015 & 1,942 kali & 2,196 kali & $0,2 \%$ \\
\hline 2016 & 1,522 kali & 1,677 kali & $-1,1 \%$ \\
\hline
\end{tabular}

Sumber: PT. Mustika Ratu, Tbk (data diolah)

Berdasarkan latar belakang tersebut, maka penulis tertarik untuk melakukan penelitian serta membahas masalah tersebut dalam skripsi yang berjudul "PENGARUH PERPUTARAN PIUTANG DAN PERPUTARAN PERSEDIAAN TERHADAP PROFITABILITAS PADA PT. MUSTIKA RATU, TBK". 


\section{B. KAJIAN LITERATUR}

\section{Manajemen Keuangan}

Menurut Kasmir (2010:5) mendefinisikan manajemen keuangan adalah segala aktivitas yang berhubungan dengan perolehan, pendanaan, dan pengelolaan aktivita dengan beberapa tujuan menyeluruh.

\section{Perputaran Piutang(Receivable Turn Over)}

Menurut Kasmir (2015:176) Perputaran piutang merupakan rasio yang digunakan untuk mengukur berapa lama penagihan piutang selama satu periode atau berapa kali dana yang ditanam dalam piutang ini berputar dalam satu periode. Sedangkan menurut Soemarso S.R (2010:393), menyatakan bahwa perputaran piutang (receivable turn over) menunjukkan berapa kali suatu perusahaan menagih piutangnya dalam suatu periode.Perputaran piutang menunjukkan efisiensi perusahaan dalam mengelola piutangnya, jika perputaran piutang rendah menunjukkan efisiensi penagihan yang buruk selama periode itu karena lamanya penagihan dilakukan. Agus Sartono (2010:119) menyatakan bahwa semakin cepat periode berputarnya piutang menunjukkan semakin cepat penjualan kredit dapat kembali menjadi kas. Menurut Bambang Riyanto (2011:90) periode perputaran atau periode terikatnya modal dalam piutang adalah tergantung kepada syarat pembayarannya. Berdasarkan uraian di atas dapat ditarik kesimpulan bahwa, jika semakin cepat perputaran piutang maka semakin efektif perusahaan dalam mengelola piutangnya.

Rumus untuk mencari Perputaran piutang dapat digunakan sebagai berikut :

$$
\text { Perputaran Piutang }=\frac{\text { Penjualan } \text { Kredit }}{\text { Rata }- \text { rata Piutang }}
$$

\section{Perputaran Persediaan(Inventory Turn Over)}

Menurut Kasmir (2015:180) Perputaran Persediaan (Inventory turn over) merupakan rasio yang digunakan untuk mengukur berapa kali dana yang ditanam dalam sediaan (inventory) ini berputar dalam satu periode. Dapat diartikan pula bahwa perputaran sediaan merupakan rasio yang menunjukkan berapa kali sediaan diganti dalam satu tahun. Adapun menurut Harmono (2011:234) Perputaran Persediaan merupakan sejauh mana persediaan dalam satu tahun dapat diperoleh dari harga pokok penjualan dibagi saldo rata-rata persediaan. Sedangkan menurut Toto Prihadi (2010:120) Perputaran Persediaan (inventory turn over) merupakan indikasi perusahaan untuk menyediakan persediaan dalam mendukung tercapainya pemjualan.

Rumus untuk mencari Perputaran Persediaan dapat digunakan sebagai berikut :

$$
\text { Perputaran Persediaan }=\frac{\text { Harga Pokok Penjualan }}{\text { Rata }- \text { rata Persediaan }}
$$

\section{Return on Asset (ROA)}

Return on Asset (ROA) merupakan salah satu rasio profitabilitas. Dalam analisis laporan keuangan, rasio ini paling sering disoroti, karena mampu menunjukkan keberhasilan perusahaan menghasilkan keuntungan. ROA mampu mengukur 
kemampuan perusahaan menghasilkan keuntungan pada masa lalu untuk kemudian diproyeksikan di masa yang akan datang.

Rumus dari ROA adalah sebagai berikut :

$$
R O A=\frac{\text { Earning After Tax }}{\text { Total assets }} \times 100 \%
$$

\section{METODOLOGI PENELITIAN}

Metode analisa data dalam penelitian ini adalah metode deskriptif kuantitatif yaitu dengan melakukan pengolahan data - data finansial perusahaan dalam bentuk laporan keuangan.

Metode analisa yang digunakan dalam penelitian ini adalah dengan menggunakan metode SPSS ( Statistical Product Service and Solution ). SPSS merupakan program atas software yang digunakan untuk mengolah data statistik. Rumus data yang digunakan peneliti dalam menyusun penelitian ini yaitu Uji Asumsi Klasik, Uji Regresi Linear Berganda, Uji Korelasi Produk Moment, Uji Hipotesis.

\section{HASIL DAN PEMBAHASAN}

1. Uji Asumsi Klasik

a. Uji Normalitas

One-Sample Kolmogorov-Smirnov Test

\begin{tabular}{|ll|r|}
\hline & & Standardized Residual \\
\hline N & & 10 \\
Normal Parameters $^{\mathrm{a}, \mathrm{b}}$ & Mean & SE-7 \\
& Std. Deviation &, 88191710 \\
& Absolute &, 146 \\
Most Extreme & Positive &, 146 \\
Differences & Negative &,- 143 \\
& &, 462 \\
Kolmogorov-Smirnov Z &, 983 \\
Asymp. Sig. (2-tailed) & & \\
\hline
\end{tabular}

a. Test distribution Normal.

b. Calculated From data.

Berdasarkan hasil uji normalitas dengan kolmogorov-smirnov test pada tabel di atas, diperoleh nilai test statistic sebesar 0,462 dan asymp.sig sebesar 0,983lebih besar dari 0,05, maka dapat disimpulkan data berdistribusi norma. 
b. Uji Multikolinearitas

\begin{tabular}{|r|r|r|}
\hline \multirow{2}{*}{ Model } & \multicolumn{2}{|c|}{ Collinearity Statistics } \\
\cline { 2 - 4 } & \multicolumn{1}{|c|}{ Tolerance } & \multicolumn{1}{c|}{ VIF } \\
\hline \multirow{2}{*}{$\begin{array}{l}\text { (Constant) } \\
1\end{array} \quad \begin{array}{r}\text { PERPUTARAN } \\
\text { PIUTANG } \\
\text { PERPUTARAN } \\
\text { PERSEDIAAN }\end{array}$} &, 539 & 1,854 \\
\hline
\end{tabular}

a. Dependent Variabel: ROA

Dari hasil uji multikolinearitas di atas diperoleh nilai Tolerance semua variabel $>0,10$ dan nilai VIF semua variabel $<10$, maka dapat disimpulkan bahwa tidak terjadi gejala multikolinearitas dalam model regresi.

c. Uji Heteroskedastisitas

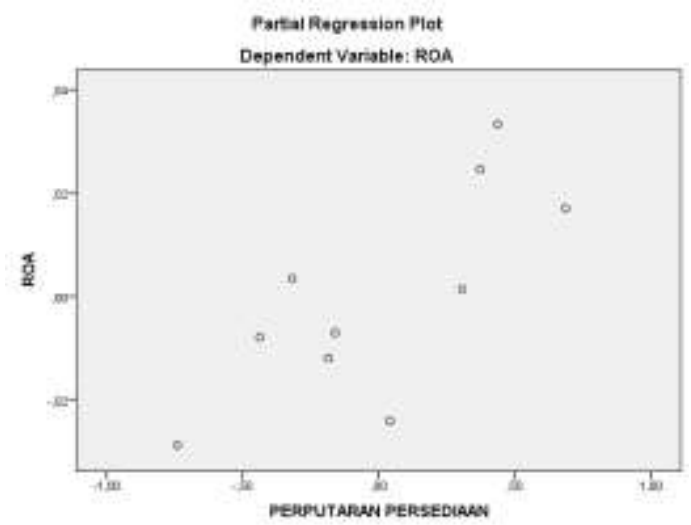

Berdasarkan gambar di atas dapat diketahui bahwa titik-titik menyebar secara acak, tidak membentuk pola spesifik yang jelas dan menyebar di atas dan di bawah nol (0) pada sumbu $\mathrm{Y}$, ini berarti tidak ada heteroskedastisitas dalam model regresi

d. Uji Autokorelasi

Uji Autokorelasi dengan Run Test

Runs Test

\begin{tabular}{|l|r|}
\hline & \multicolumn{1}{|c|}{ Standardized Residual } \\
\hline Test Value $^{\text {a }}$ &,- 16208 \\
Cases $<$ Test Value & 5 \\
Cases $>=$ Test Value & 5 \\
Total Cases & 10 \\
Number of Runs & 6 \\
$Z$ &, 000 \\
Asymp. Sig. (2-tailed) & 1,000 \\
\hline
\end{tabular}

Berdasarkan tabel diatas, hasil uji statistik runs test diatas menunjukkan bahwa nilai Asymp.Sig (2-tailed) sebesar 1,000> 0,05. Dengan demikian data yang 
dipergunakan cukup random sehingga tidak terdapat gangguan autokorelasi pada data regresi yang diuji.

\section{Uji Regresi Linear Berganda}

\begin{tabular}{|c|c|c|c|c|c|c|}
\hline \multicolumn{7}{|c|}{ Hasil Analisis Regresi } \\
\hline \multirow{2}{*}{\multicolumn{2}{|c|}{ Model }} & \multicolumn{2}{|c|}{$\begin{array}{l}\text { Unstandardized } \\
\text { Coefficients }\end{array}$} & \multirow{2}{*}{$\begin{array}{c}\text { Standardized } \\
\text { Coefficients } \\
\text { Beta }\end{array}$} & \multirow[t]{2}{*}{$\mathrm{t}$} & \multirow[t]{2}{*}{ Sig. } \\
\hline & & $\mathrm{B}$ & Std. Error & & & \\
\hline \multirow{3}{*}{1} & (Constant) &,- 123 & ,026 & & $-4,686$ & ,002 \\
\hline & $\begin{array}{l}\text { PERPUTARAN } \\
\text { PIUTANG }\end{array}$ & ,026 & ,014 & ,376 & 1,869 & ,104 \\
\hline & $\begin{array}{l}\text { PERPUTARAN } \\
\text { PERSEDIAAN }\end{array}$ & ,034 & 011 & ,623 & 3,099 & ,017 \\
\hline
\end{tabular}

a. Dependen Variabel: RO

Dari tabel di atas doperoleh ersamaan regresi linear berganda sebagai berikut : $\mathbf{Y}=$ $\mathbf{0 , 1 2 3 + 0 , 0 2 6} \mathrm{X}_{\mathbf{1}}+\mathbf{0 , 0 3 4} \mathrm{X}_{\mathbf{2}}$ Persamaan linear berganda di atas mempunyai arti dimana karena nilai koefisiennya bernilai negatif maka terjadi hubungan yang negatif antara perputaran Piutang dan Perputaran Persediaan terhadap ROA.

\section{Uji Hipotesis}

a. Uji Koefisien Determinasi

Hasil Uji Koefisien Determinasi
Model Summary
\begin{tabular}{|l|r|r|r|r|}
\hline Model & \multicolumn{1}{c|}{ R } & R Square & Adjusted R Square & Std. Error of the Estimate \\
\hline 1 &, $920^{\text {a }}$ &, 847 &, 804 &, 01491 \\
\hline
\end{tabular}
a. Predictors: (Constant), PERPUTARAN PERSEDIAAN, PERPUTARAN PIUTANG
b. Dependent Variable: ROA

Dari hasil perhitungan di atas, kontribusi variabel independen terhadap variabel dependen yang dapat dijelaskan oleh persamaan ini adalah 0,847. Hal ini menunjukkan bahwa besarnya kontribusi perputaran piutang dan perputaran persediaan terhadap Return on Asset $(\mathrm{ROA})$ yang dapat dijelaskan oleh model persamaan ini adalah $84,7 \%$ dan sisanya $15,3 \%$ dipengaruhi oleh faktor lain yang tidak termasuk dalam model regresi.

c. Uji T ( Parsial )

Hasil Uji T

\begin{tabular}{|c|c|c|c|c|c|}
\hline \multicolumn{6}{|c|}{ Coefficients $^{a}$} \\
\hline \multirow[t]{2}{*}{ Model } & \multicolumn{2}{|c|}{ Unstandardized Coefficients } & Standardized & $\mathrm{t}$ & Sig. \\
\hline & $B$ & Std. Error & Beta & & \\
\hline (Constant) &,- 123 &, 026 & & $-4,686$ &, 002 \\
\hline PIUTANG & ,026 & 014 &, 376 & 1,869 & ,104 \\
\hline
\end{tabular}

a. Dependen Variabel: ROA

Berdasarkan tabel diatas menyatakan bahwa nilai $t_{\text {hitung }}$ untuk perputaran piutang sebesar1,869 berdasarkan perhitungan SPSS ver.20 diperoleh 0,104> 0,05, 
sehingga dapat disimpulkan bahwa $\mathrm{HO}$ diterima dimana tidak ada pengaruh antara perputaran piutang terhadap return on asset (ROA).

Hasil Uji T

\begin{tabular}{|c|c|c|c|c|c|}
\hline \multirow[t]{2}{*}{ Model } & \multicolumn{2}{|c|}{$\begin{array}{c}\text { Unstandardized } \\
\text { Coefficients }\end{array}$} & $\begin{array}{c}\text { Standardized } \\
\text { Coefficients }\end{array}$ & $t$ & Sig. \\
\hline & $\mathrm{B}$ & Std. Error & Beta & & \\
\hline (Constant) &,- 123 & ,026 & & $-4,686$ & ,002 \\
\hline $\begin{array}{l}\text { PERPUTARAN } \\
\text { PERSEDIAAN }\end{array}$ & ,034 & ,011 & ,623 & 3,099 & ,017 \\
\hline
\end{tabular}

Berdasarkan tabel diatas menunjukkan bahwa nilai $t_{\text {hitung }}$ untuk perputaran persediaan sebesar 3,099dengan taraf signifikan berdasarkan perhitungan SPSS ver.20 diperoleh 0,017<0,05, dengan demikian dapat disimpulkan bahwa $\mathrm{Ha}$ diterima.hal ini menunjukkan bahwa terdapat pengaruh antara perputaran persediaan terhadap return on asset (ROA).

d. Uji F ( Simultan )

Hasil Uji F

\begin{tabular}{|l|r|r|r|r|r|}
\hline Model & Sum of Squares & Df & Mean Square & F & \multicolumn{1}{c|}{ Sig. } \\
\hline \multicolumn{1}{|c|}{ Regression } &, 009 & 2 &, 004 & 19,422 &, $001^{\mathrm{b}}$ \\
$1 \quad$ Residual &, 002 & 7 &, 000 & & \\
\multicolumn{1}{|c|}{ Total } &, 010 & 9 & & & \\
\hline
\end{tabular}

a. Dependent Variable: ROA

b. Predictors: (Constant), PERPUTARAN PERSEDIAAN, PERPUTARAN PIUTANG

Berdasarkan tabel diatas bahwa nilai $F_{\text {hitung }}$ sebesar 19,422 dan $F_{\text {tabel }}$ sebesar 4,74 sehingga $F_{\text {hitung }}>F_{\text {tabel. }}$. Hal ini menunjukkan bahwa menerima Ha yang memberikan kesimpulan bahwa tardapat pengaruh diantara perputaran piutang (receivable turn over) dan perputaran persediaan (inventory turn over) secara simultan terhadap return on asset. Karena probabilitasnya kurang dari 0,05 atau 5\%, maka model regresi dapat digunakan untuk memprediksi return on asset.

\section{E. KESIMPULAN}

\section{Kesimpulan}

Berdasarkan hasil penelitian, serangkaian pengolahan data dan analisis serta pembahasan mengenai pengaruh variabel perputaran piutang(receivable turn over) dan perputaran persediaan (inventory turn over) terhadap return on asset (ROA), maka dapat ditarik kesimpulan yaitu sebagai berikut :

1. Berdasarkan analisis uji t diketahui bahwa secara parsial perputaran piutang(receivable turn over) tidak berpengaruh signifikan terhadap return on asset (ROA), karena nilai $t_{\text {hitung }}$ untuk perputaran piutang sebesar 1,869 dan dengan taraf signifikan sebesar 0,104>0,05, dengan demikian hasil analisis tersebut diketahui bahwa $\mathrm{HO}$ diterima dan $\mathrm{Ha}$ ditolak. 
2. Sedangkan uji t perputaran persediaan (inventory turn over) secara parsial berpengaruh signifikan terhadap return on asset (ROA), karena nilai $t_{\text {hitung }}$ untuk perputaran persediaan sebesar 3,099 dan dengan taraf signifikan sebesar $0,017<0,05$, dengan demikian hasil analisis tersebut diketahui bahwa $\mathrm{HO}$ ditolak dan Ha diterima.

3. Berdasarkan uji F menyatakan bahwa secara simultan seluruh variabel bebas yang terdiri dari perputaran piutang(receivable turn over) dan perputaran persediaan (inventory turn over) menunjukkan pengaruh signifikan terhadap variabel terikat return on asset (ROA).

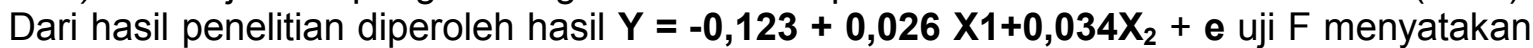
bahwa perputaran piutang (receivable turn over) dan perputaran persediaan (inventory turn over) secara simultan berpengaruh signifikan terhadap return on asset (ROA) dengan nilai signifikan sebesar 0,001<0,05, maka ini berarti $\mathrm{HO}$ ditolak dan Ha diterima artinya perputaran piutang (receivable turn over) dan perputaran persediaan (inventory turn over) secara simultan mempengaruhi return on asset.

\section{SARAN}

Berdasarkan pembahasan dan kesimpulan penelitian ini serta dari analisis data yang telah diteliti, maka peneliti memberikan saran-saran sebagai berikut :

1. Perusahaan sebaiknya lebih memperhatikan unsur-unsur yang terdapat dalam aktiva lancer seperti persediaan dalam komposisinya, sehingga dapat meningkatkan profitabilitas perusahaan.

2. Bagi peneliti selanjutnya, disarankan untuk menggunakan tahun penelitian yang lebih panjang dan dapat menambah variabel lain yang lebih luas dan spesifik serta menggunakan faktor-faktor lain selain perputaran piutang(receivable turn over) perputaran persediaan (inventory turn over) dan return on asset (ROA). 


\section{DAFTAR PUSTAKA}

Agus, Ristono. 2009. “Manajemen Persediaan”. Yogyakarta : Graha IImu.

Brigham E.F dan Joel F. Houtson. 2010. "Dasar-dasar Manajemen Keuangan”.Buku I Edisi II.Jakarta : Salemba Empat.

Carls S. Warren, James M. Reeve dan Philip E. Fess. 2009. "Pengantar Akuntansi". Edisi 21.Jakarta : Salemba Empat.

Fahmi, Irham. 2013. “Analisis Laporan Keuangan”.Bandung : Alfabeta.

Ghozali, Imam.2013. "Aplikasi Analisis Multivariate Dengan Program IBM SPSS”.Edisi 7.Semarang : Badan Penerbit Universitas Diponegoro.

Hanafi, Mamduh M. 2016. "Analisis Laporan Keuangan". Edisi 5.Yogyakarta : UPP STIM YKPN.

Handoko, T Hani. 2009. “Manajemen” Cetakan 20. Yogyakarta : Penerbit BPEE.

Harahap, Sofyan Syafri. 2011. "Analisis Kritis Atas Laporan Keuangan”. Jakarta: Raja Grafindo Persada.

Harmono. 2009. "Manajemen Keuangan Berbasis Balanced Scorecard Pendekatan Teori, Kasus, dan Riset Bisnis".Edisi 1.Jakarta : Bumi Aksara.

Hasibuan, Malayu S.P. 2009."Manajemen : Dasar, Pengertian, Masalah". Edisi Revisi. Jakarta : Bumi Aksara.

Hendra S. , Rahaja Putra. 2009. "Manajemen Keuangan Dan Akuntansi Untuk Eksekutif Perusahaan". Jakarta : Pt. Raja Grafindo Persada.

Hery. 2012. “Analisis Laporan Keuangan”.Jakarta : PT. Bumi Aksara.

Horne, James C Van dan John M Wachowicz. 2012. Prinsip-Prinsip Manajemen Keuangan. Edisi 13. Jakarta: Salemba Empat.

Kadim, A., \& Sunardi, N. (2019, May). Eviews Analysis; Determinan Tourism, Restaurant and Hotel Company's Soundness and Performance. In Proceeding Interuniversity Forum for Strengthening Academic Competency (Vol. 1, No. 1, pp. 332-340).

Kasmir. 2015. “Analisis Laporan Keuangan”.cetakan kelima, PT. Raja Grafindo Persada, Jakarta.

Kasmir.2010. Pengantar Manajemen Keuangan, Edisi Pertama. Jakarta : KENCANA PRENADA MEDIA GROUP.

Kuncoro, Mudrajad. 2011. "Metode Kuantitatif (Teori Dan Aplikasi Untuk Bisnis Dan Ekonomi)". Yogyakarta : UPP AMP YKPM.

Martono dan Agus Harjito. 2010. “Manajemen Keuangan”.Edisi 3.Yogyakarta : Ekonosia.

Munawir, S. 2016. “Analisa Laporan Keuangan”.edisike-5, Liberty, Yogyakarta.

Jurnal SEKURITAS (Saham, Ekonomi, Keuangan dan Investasi ), Vol.3, No.2 , Januari 2020........185 
Prihadi, Toto. 2010. “Analisis Laporan Keuangan Teori Dan Aplikasi”. Jakarta : PPM.

Riyanto, Bambang. 2010. “Dasar-dasar Pembelanjaan Perusahaan”.Edisi 4.Yogyakarta : BPFE Yogyakarta.

Robbins, Stephen P. dan Mary Coulter. 2010. “Manajemen”.Jakarta : Erlangga.

Rudianto. 2009. “Pengantar Akuntansi”.Jakarta : Erlangga.

Sartono, Agus. 2010."Manajemen Keuangan Teori dan Aplikasi". Cetakan Keempat. Yogyakarta : BPFE-Yogyakarta.

Soemarso. 2010. “Akuntansi Suatu Pengantar”.Edisi 5.Cetakan ke-6.Jakarta : Rineka Cipta.

Sugiyono. 2012. “Metode Penelitian Kuantitatif Kualitatif dan R\&D”.Bandung : Alfabeta.

Sunardi, N. (2017). Determinan Intelectual Capital dengan Pendekatan iB-VAIC ${ }^{\text {тM }}$ Terhadap Efisiensi Biaya Implikasinya Pada Profitabilitas Perbankan Syariah di Indonesia. JIMF (Jurnal Ilmiah Manajemen Forkamma), 1(1).

Sunardi, N. (2017). Determinan Kebijakan Utang Serta Implikasinya terhadap Kinerja Perusahaan (Perusahaan yang tergabung dalam indeks LQ. 45 yang terdaftar di Bursa Efek Indonesia Tahun 2011-2015). Jurnal Sekuritas, 1(1).

Sunardi, N. (2018). Analisis Du Pont System Dengan Time Series Approach (Tsa) Dan Cross Sectional Approach (Csa) Dalam Penilaian Kinerja Keuangan Perusahaan (Studi Pada Industri Konstruksi (BUMN) di Indonesia Yang Listing di BEI Tahun 20132017). Jurnal SEKURITAS (Saham, Ekonomi, Keuangan dan Investasi), 1(4).

Sunardi, N. (2018). Analisis Economic Value Added (Eva), Financial Value Added (FVA) Dan Market Value Added (MVA) Dengan Time Series Approach Sebagai Alat Penilaian Kinerja Keuangan (Studi Pada Industri Konstruksi (BUMN) di Indonesia Yang Listing di BEI Tahun 2013-2017). Jurnal SEKURITAS (Saham, Ekonomi, Keuangan dan Investasi), 2(1).

Sutrisno. 2012. “Manajemen Keuangan: Teori, Konsep \& Aplikasi”. Edisi Revisi. 